\title{
THE EFFECT OF MILLING TIME AND PERCENTAGE OF DISPERSING AGENT ON THE CHARACTERISTIC OF SOLVENT-BASED BLACK PAINT FROM CARBON BLACK PIGMENT
}

\author{
Ratnawati $^{1}$, Joko Noveriarto ${ }^{1}$, Aniek S. Handayani, \\ Is S. Purwaningsih ${ }^{1}$ and Iyus Hendrawan ${ }^{2}$ \\ ${ }^{1}$ Chemical Engineering Department, Institut Teknologi Indonesia \\ Jalan Raya Puspiptek Serpong15320, Tangerang Selatan \\ ${ }^{2}$ Mechanical Engineering Department, Institut Teknologi Indonesia \\ Jalan Raya Puspiptek Serpong 15320, Tangerang Selatan \\ E-mail:rnwt63@yahoo.co.id
}

\begin{abstract}
THE EFFECT OF MILLING TIME AND PERCENTAGE OF DISPERSING AGENT ON THE CHARACTERISTIC OF SOLVENT-BASED BLACK PAINT FROM CARBON BLACK PIGMEN. The need for black paint made from carbon black pigment increasing year by year especially in the automotive world. The production of black paint is performed by milling the resin, pigment, additive/dispersing agent, and solvent. In the manufacturing process, it takes a relatively long time with precise dispersing agent composition toward pigment to get the product with blackness/solid black according to the expected quality. This work aims to study the role of the milling time of carbon black fw 200 beads on a 3 liter ball mill and the percentage of dispersing agents on paint color quality, especially blackness. The variations in milling time were 36,48 , and 60 hours and the weight percentage of dispersing agent toward pigment were $80 \%, 100 \%$, and $120 \%$. The optimum results obtained are at the milling time of 48 hours and on the percentage of dispersing agent of $120 \%$ with the product characteristics fulfills the requirement namely: $10 \mu \mathrm{m}$ of particle fineness, $111.5 \mathrm{krebs}$ unit of viscosity, $36.97 \%$ of solid content, $0.9839 \mathrm{gr} / \mathrm{cc}$ of specific gravity with desirable solid black color.
\end{abstract}

Keywords: Carbon black, Dispersing agent, Milling

\begin{abstract}
ABSTRAK
PENGARUH WAKTU MILLING DAN PERSENTASE DISPERSING AGENT TERHADAP KARAKTERISTIK PRODUK CAT HITAM SOLVENT-BASED DARI PIGMENT CARBON BLACK. Kebutuhan cat warna hitam berbahan pigmen carbon black mengalami peningkatan terutama dalam dunia automotif. Pembuatan cat warna hitam dilakukan dengan menggiling/milling campuran antara resin, pigmen, additive/dispersing agent dan pelarut. Dalam pembuatannya, diperlukan waktu yang cukup lama dengan komposisi dispersing agent terhadap pigmen yang tepat agar didapatkan produk dengan warna hitam pekat sesuai kwalitas yang diinginkan. Penelitian ini bertujuan untuk mempelajari pengaruh waktu milling pigmen carbon black fw 200 beads pada ballmill ukuran 3 liter dan efek persentase dispersing agent terhadap kualitas warna cat yang dihasilkan terutama blackness. Variasi waktu milling adalah 36, 48 dan 60 jam serta persentase berat dispersing agent terhadap pigmen sebesar $80 \%, 100 \%$ dan $120 \%$. Hasil optimal yang didapatkan adalah waktu milling 48 jam pada persentase dispersing agent $120 \%$ dengan karakteristik produk yang dihasilkan telah memenuhi syarat yaitu: kehalusan partikel $10 \mu \mathrm{m}$, viscositas $111,5 \mathrm{krebs}$ unit, kadar padatan/solid content $36,97 \%$, berat jenis $0,9839 \mathrm{gr} / \mathrm{cc}$ dan warna hitam pekat yang diinginkan.
\end{abstract}

Kata kunci: Carbon black, Dispersing agent, Milling 


\section{INTRODUCTION}

The growth of the paint market in Indonesia is rapidly growing, which increased by $10 \%$ in 2012 . The paint color is caused by dyes/pigments such as $\mathrm{TiO}_{2}$ for white colorant and carbon black for black color $[1,2]$. Black paint has the second rank of attraction by car consumers. It is in high demand because it has an elegant impression and is not easy to get dirty. The black paint formed from carbon black pigment material is one of the most commonly used pigments in the paint/coating industry because it has a good level of concentration in its application and protects it from ultraviolet rays [1]. Besides, carbon black is also used as fillers in natural rubber [3] and the ink industry [4]. The pigment classified as an organic and inorganic doe to chemical nature is usually powdery and insoluble in some organic solvent and water [5]. Several factors that influence the selection of pigments are hardness, size, and solubility of pigments in the dispersion media, the effectiveness of the dispersants, and the design of the milling device $[6,7]$.

The process of making paint is dispersing pigments into the resin and solvent utilizing the material being mixed (pre-mixing) in a tank with the addition of additive/dispersing agent. The interaction of dispersant/ additives in paint is essential to get a good quality of paint product. Subsequently, the milling process will be carried out and followed by the let-down process [8]. Pigment milling is needed to break up its agglomeration and reduce the particle size [5]. The selection of equipment and the order in which they are made depends on the type of coating and the quantity of the product [9]. Paints consist mainly of five components: resin, pigment, solvent, additives, and filler [10]. Resin is the primary material polymer of paint. At room temperature is thick, stable viscosity, which serves to form films, bind fillers and pigments, and provide adhesion to the surface of the substrate. The function of pigments or dyes is for aesthetics and protection. A solvent is a liquid that can dissolve resins and allow the mixing of pigments and resins. The additive is an ingredient added to paint in small quantities to improve the ability to paint according to its function and application. The addition and selection of additives in the paint manufacturing is a long process of several experiments or research with many variations in types and quantities according to the type of pigment, resin, and solvent.

The main target in the coating manufacturing process is the perfect blending of all materials and the optimal pigment dispersion process [6] with the dispersion mechanism that has been reported by previous researchers [11]. The milling process requires time, which is affected by the stirring speed, type, and size of the beads on the milling device. This process is intended to reduce size, narrow particle size distribution, and increase stability [12]. The length and type of the milling device are closely related to the paint production costs. The longer the milling process, the smaller the viscosity, marked by the fineness of the particles achieved that meets the desired standards of quality [6]. The percentage of additive/dispersing agents also affects the fineness of the particles and color. The more the dispersing agents are used, the more the particle size becomes smoother. Moreover, the resulting color becomes more concentrated. The choice of dispersing agent is determined by the characteristics of the pigment and the milling device's design to obtain a homogeneous dispersion of the pigment [1,7]. In comparison, the amount of dispersing agents for some pigments has been studied by previous researchers [13]. For carbon black pigment, studies on the selection of suitable dispersant types have been studied by previous researchers, including their adsorption abilities, surface interactions, and their coloring properties [1].

The milling process from one of the paint factories in Tangerang that produces solvent-based black paint with carbon black pigment requires 60 hours of milling. The trademark of carbon black is fw 200 beads. This process is considered too long. Therefore, this research is carried out to vary the milling time below 60 hours, but the paint result still meets the desired product specifications. If the optimum milling time bellow 60 hours, it will increase the time efficiency that can save energy needed. Furthermore, the composition of the dispersing agent BYK-170 to carbon black pigments is $70-140 \%$ listed in the Technical Data Sheet (TDS) as a recommendation level. The BYK-170 is a solution of a high molecular weight block copolymer with pigment affinic groups. Therefore, the two above factors need to be studied in detail to get the optimum condition.

This study aims to obtain the optimum milling time and weight percentage of additive/dispersing agent toward pigment to get the characteristics of solventbased black paint products. The pigment used was carbon black and the product obtained should meet the maximum particle fineness specifications of $10 \mu \mathrm{m}$, the viscosity of 108-115 krebs units, solid content of 34$38 \%$, the specific gravity of $0.93-1.00 \mathrm{gr} / \mathrm{cc}$ and the desired color (" $L^{*}=73.3 ; a^{*}=-4.7 ; b *=4.07$ ). This specification is based on the paint factory's desired product to produce black color for car paint application.

\section{EXPERIMENTAL}

\section{Materials}

The materials used are alkyd resin as a binder ( $60 \%$ non-volatile, supplier of PT Paint resin unit), butyl cellosolve as solvent (purity 99\%, supplier of PT. Indochemicals Citra Kimia), xylene as solvent (purity $99.8 \%$, supplier of PT Indochemicals Citra Kimia), additive as dispersing agent (non-volatile $30 \%$, supplier BYK - Chemie), carbon black fw 200 beads as a pigment (44 $\mu \mathrm{m}$ particle size distribution, supplier Evonic). 
The equipment used in this study was the Ball mill machine FEQ-F type with a speed of $200-400 \mathrm{rpm}$ to reduce the particle size (Drive Corporation), Grindometer GW-2532 for fineness or size test with measurement specifications from 0-100 $\mu \mathrm{m}$ (Taiyu), Mixer Despa 2.5 version with specifications 000-10000 rpm (Tokushu Kika), Rotating Viscometer sheen ref 480 for measuring viscosity from 0-150 krebs unit (Sheen Instrument), Spectrophotometer for color testing with reading specifications DE ("L*a*b*) (Datacolor 800), Oven OGH 100 Heratherm for a total solid test with temperature specifications 0-330p C (Heratherm), Analytical balance XB 4200C for weighing 0.0001 - 4200 gr (Precisa), Stem Applicator (Dr. blade) with test specifications 50, 75, $100,125 \mu \mathrm{m}$ (Sheen), Cans (made of iron plate) and Spatula for premixing paint samples.

\section{Methods}

\section{Solvent-Based Black Paint}

The paint production procedure is performed by mixing alkyd resin, carbon black pigment, additive/ dispersing agent (with variation $80,100,120 \% \mathrm{w} / \mathrm{w}$ of pigment), and a certain amount of solvent in the ball mill tank until perfect mixing. The weight ratio between pigment and resin is 3:100. To blend materials and grind powders into fine particles, a mechanical ball milling is used due to a cost-effective technique [14]. The ball mill used is 3 liters in volume, speed 200-400 rpm with a diameter of beads was $50 \mathrm{~mm}$. Moreover, the milling process is carried out with the time variation of 36,48 , and 60 hours. The selection of milling times is based on the reasons previously mentioned, while the variation of percentage dispersing agent is based on supplier recommendations range in TDS.The fineness test is done after the milling time has finished. To get the desired paint product, the material namely resin, solvents, and additives are added. Finally, the viscosity, solid content, density, and color levels are tested.

\section{Product Characterization}

According to the Japanese International Standard JIS K5400-4.7 [15], product characterization is carried out according to the parameters of particle fineness testing using a Grindometer. Product specifications for the desired fineness are d"10 $\mu \mathrm{m}$. ASTM D562 [16] is used for viscosity testing using a Rotating Viscometer Sheen device with product specifications 108-115 krebs units. Solid content testing is performed using the oven at $150{ }^{\circ} \mathrm{C}$ with $34-38 \%$ product specifications based on JIS K5407-4.3.1 [17]. Density testing of paint is carried out based on JIS K54004.6.2 [18], with specifications $0.930-1.00 \mathrm{gr} / \mathrm{cc}$. In comparison, ASTM D2066-03 [19] was used for color testing (" $\mathrm{L} * \mathrm{a}^{*} \mathrm{~b} *$ ) with a Spectrophotometer Data Color.

\section{RESULTS AND DISCUSSION}

The results can be depicted in the following figures.

\section{The Effect of Milling Time with Different Percentage of Dispersing Agent on Fineness}

Figure 1 shows the effect of milling time $(36 ; 48$; and 60 hours) with different percentages of dispersing agents $(80 ; 100$ and $120 \%)$ on fineness. Therefore, 9 results of paint fineness were available.

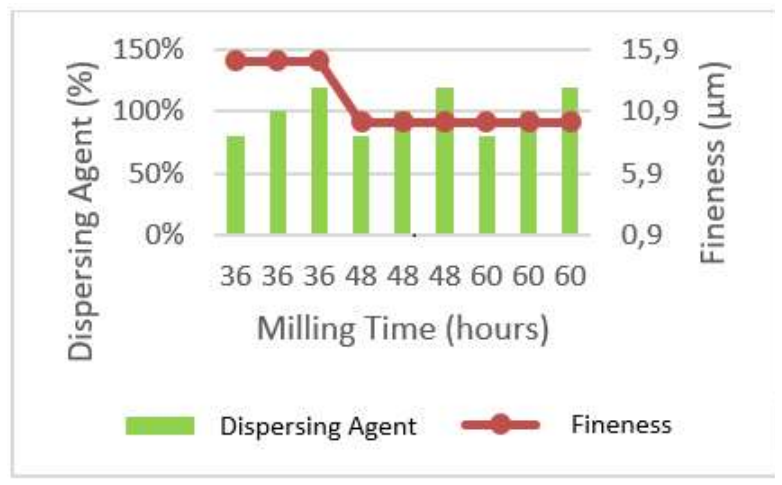

Figure 1. The effect of milling time with different percentage of dispersing agent on fineness.

Figure 1 shows that the longer the milling process, the finer the paint particles produced since collisions between particles (pigments and resins) are more intensive, which will reduce particle size. The effect of milling time on the size of the particle was also studied by many researchers [20,21]. Increasing the milling time reduced the particle clustering and resulted in the homogenous particle dispersion [22]. In this study, the optimum milling time is 48 hours with the resulting paint fineness fulfills the standard of $\leq 10 \mu \mathrm{m}$. Although at 60 hours of milling time provides $10 \mu \mathrm{m}$ of fineness, it will be better at 48 hours of milling time in terms of energy required. The breakdown of pigment particles dispersed into the resin causes the material to become smooth (up to a certain size), which is a function of polarity and face tension [23]. The fineness level significantly affects the contrast ratio, which is the paint's ability to cover the substrate. Meanwhile, the study results showed that the composition of the dispersing agent did not affect fineness due to the small range of the dispersing agent used. Supposedly, the composition of the dispersing agent also affects the fineness because of its function to facilitate the dispersion and uniformity of the pigment's face tension into the resin. The size and distribution of particles can be controlled by varying the amount of dispersant used [5]. However, if the difference in the composition of the dispersing agent is not much, then this condition will not affect the fineness. 


\section{Effect of Milling Time with Different Percentage of Dispersing Agent on Viscosity}

Figure 2 depicts the effect of milling time $(36 ; 48$; and 60 hours) with different percentages of dispersing agents $(80 ; 100$ and $120 \%)$ on viscosity. It can be stated that the longer the milling time, the higher the viscosity. This phenomenon is contrary to the results reported by other researchers that the longer the milling process, the viscosity of the paint decreases, and the smaller the particle size, the smaller the viscosity [6]. This difference occurs since in this study, the paint produced is solventbased. Therefore, the pigment has absorption capacity to the solvent, and the smaller the carbon black particles, the higher the absorption power. Consequently, the amount of solvent was reduced, which resulted in higher viscosity. Besides, the longer the milling time causes the solvent underwent evaporation due to increasing temperature in the process. The length of the milling time allows the length of contact of the paint with the balls on the ball mill so that the temperature becomes a little higher which causes the solvent evaporation and increasing the viscosity [2]. For the concentration of dispersing agent variation, it does not significantly affect the viscosity since the amount of dispersing agent used is not in enormous quantities and not as a diluent. Although there is an effect of milling time and percentage of dispersion agent variations on a viscosity that previously explained, the paint viscosity fulfills the desired product specifications of 108-115 kerbs unit.

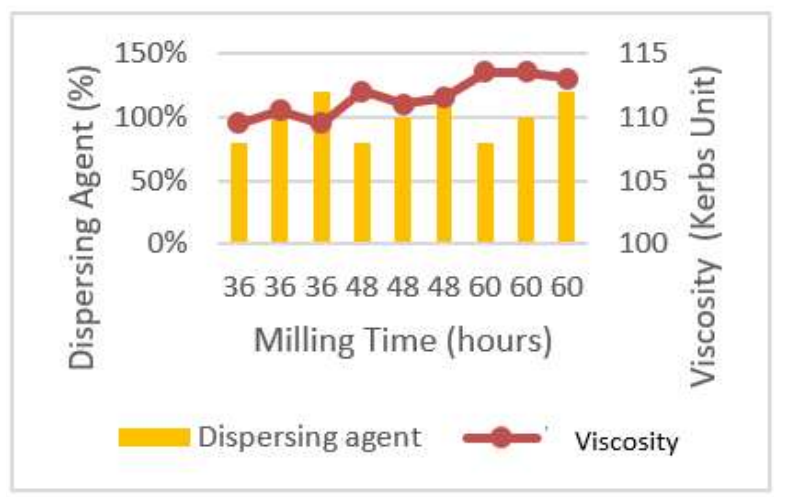

Figure 2. Effect of milling time with different percentage of dispersing agent on viscosity .

\section{The Effect of Milling Time with Different Percentage of Dispersing Agent on Solid Content}

Figure 3 presents the effect of milling time (36; 48; and 60 hours) with different percentages of dispersing agents $(80 ; 100$ and $120 \%)$ on solid content. Solid content is defined as the amount of solids in paint that is measured by the gravimetric method. The milling time variations did not significantly affect the solid content produced. From Figure 3, it can be stated that the higher the percentage of dispersing agent, the higher the solid content. For all variations obtained, solid content values still meet the desired standard of $34-38 \%$ by weight of the pigment, except for 48 hours of milling time with dispersing agent $100 \%$ the solid content was $38.30 \%$.

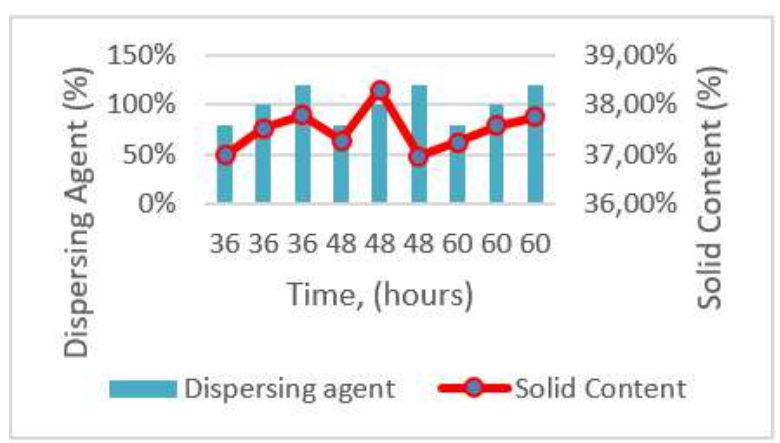

Figure 3. Effect of milling time with different percentage of dispersing agent on solid content.

\section{The Effect of Milling Time with Different Percentage of Dispersing Agent on Density}

Figure 4 shows that the milling time does not affect the density of the paint, and the higher the dispersing agent, the greater the density. The density fulfills the requirements for all variations, which have the values between $0.95-0.98 \mathrm{gr} / \mathrm{cc}$.

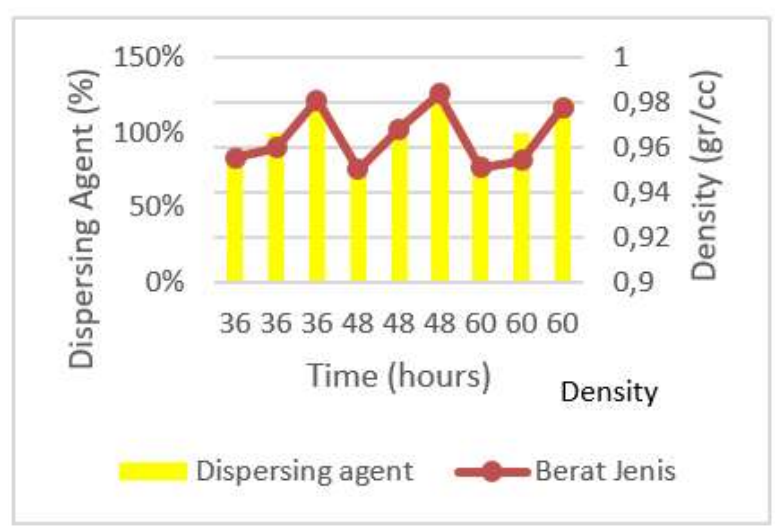

Figure 4. effect of milling time with different percentage of dispersing agent on density.

\section{The Effect of Milling Time with Different Percentage of Dispersing Agent on Color}

The color is tested by spectrophotometer data color, which is seen based on wavelengths and light reflected by paint. The particle size influences on the reflection of light and color [24]. Figure 5 describes the value of $\Delta \mathrm{L}^{*}$, which represents the difference in the level of brightness. The smaller " $\mathrm{L}$ * indicates the darker color, while the higher " $\mathrm{L}^{*}$ points out the lighter color [25], according to International Commission on Illumination (CIE 1976 L* a* $b^{*}$ color space) [26]. The $a^{*}, b^{*}$ chart is 
a useful way of displaying colors in a color space. Color can be determined using the coordinates $a^{*}$ and $b^{*}$, where the positive value of $\mathrm{a}^{*}$ indicates the red color, and the negative value of $\mathrm{a}^{*}$ indicates green color. While $b^{*}$ represents the yellow/blue difference, with a positive value of $b^{*}$ indicating a yellow and negative value of $b^{*}$ indicating blue. Figure 4 shows that the composition of the dispersing agent is not very influential on the value of (" $\left.\mathrm{L}^{*} \mathrm{a}^{*} \mathrm{~b}^{*}\right)$. However, in the milling time variation, the longer the milling process, the darker the resulting paint color. It is indicated by 60 hours of milling time obtained a value of " $\mathrm{L} *$ is a little smaller than the milling time of 36 hours and 48 hours, although the difference is not too significant. For the $a^{*}$ value obtained from this study, the results are negative (-4.7), and the $b^{*}$ value is positive (4.07). This result shows that the carbon black pigment fw-200 beads have the resulting color properties of black with a yellowish-green tone. The mechanical power transferred to the ball mill is related to stirring, which affects the particle size distribution, which will influence the color produced $[25,27]$.

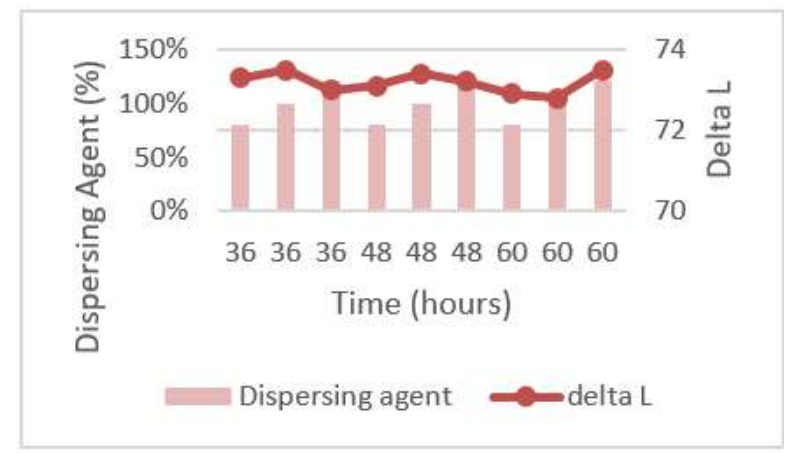

Figure 5. effect of milling time with different percentage of dispersing agent on color.

\section{CONCLUTION}

In this study, the milling time affects the smoothness, viscosity, and color of the paint, but it does not affect the solids content and specific gravity. While the percentage of dispersing agents affects the solid content and specific gravity, but it has less effect on fineness, viscosity, and color. The optimal milling time to disperse carbon black pigment into resin is 48 hours with the weight percentage of the dispersing agent is $120 \%$. In this condition, the product characteristics is according to the desired paint quality and considering its energy requirements.

\section{ACKNOWLEDGMENT}

The authors would like to thank Pusat Riset dan Pengabdian Masyarakat (PRPM) Institut Teknologi Indonesia and the paint factory in Tangerang for the opportunity to conduct this study.

\section{REFFERENCES}

[1] F. Nsib, N. Ayet, Y. Chevalier. "Selection of Dispersants for The Dispersion of Carbon Black in Organic Medium”. Progress in Organic Coating, vol 55, pp 303-310, 2006.

[2] Ratnawati, L. A. Yoshi, Z. Kurniawan, A. Yulianto. "Pengaruh Waktu Dan Kecepatan Pengadukan Terhadap Karakteristik Produk White Colorant Dari Titanium Dioksida”. Jurnal Sains Materi Indonesia, vol, pp 61-65, 2018.

[3] I. M. Ulfah, R. Fidyaningsih, S. Rahayu, D. A. Fitriyani, D. A. Saputra, D. A. Winarto, L. A. Wisojodharmo. "Influence of Carbon Black and Silica Filler on the Rheological and Mechanical Properties of Natural Rubber Compound". Procedia Chemistry, vol 16, pp 258-264, 2015.

[4] C. Phillips, A. Al-Ahmadi, S. Jane., T. Claypole, D. Deganello. "The Effect of Graphite and Carbon Black Ratios on Conductive Ink Performance". Journal of Material Science, vol 52, pp 9520-9530. 2017.

[5] C. Agbo, W. Jakpa, B. Sarkodie, A. Boakye, S. Fu. "A Review on the Mechanism of Pigment Dispersion". Journal of Dispersion Science and Technology, vol 38, pp. 1-17, 2017.

[6] M. Ali, L. Lin. "Optimization and Analysis of Bead Milling Process for Preparation of Highly Viscous, Binder-Free Dispersions of Carbon Black Pigment". Progress in Organic Coating, vol 119, pp 1-7, 2018.

[7] F. Nsib, N. Ayed, Y. Chevalier. "Selection of Dispersants for the Dispersion of C.I. Pigment Violet 23 In Organic Medium”. Dyes and Pigments, vol 74, pp 133-140, 2007.

[8] M. Ali, "Preparation, Characterization and Application of Printed Electronic Textile Assemblies". University of Leeds, Leeds, 2013.

[9] C. Cynthia. "Production Equipment: Dispersion and Grinding Overview". Journal of Coating Technology, vol 78, 2006.

[10] A. R. M. A. Youssef. "PAINTS INDUSTRY Raw Materials \& Unit Operations \& Equipment \& Manufacturing \& Quality". Thesis, Higher Technological Institute of Ramadan City, pp. 1-46, 2019.

[11] L. Lin. "Mechanisms of pigment Dispersion". Pigment Resin Technology, vol 32, pp 78-88, 2003.

[12] H. Way. "High-flow grinding and dispersion", Paint Coatings Industry, vol 23, pp 90-96, 2007 (Article).

[13] M. Ali, S.R. Bysouth. "High Throughput Process of Optimization of Pigment Concentrates". NED Journal Research-Applied Science, vol XI, no 4, pp 15-23, 2014.

[14] C. C. Piras, S. Fern'andez-Prietob, W. M. D. Borggraeve. "Ball milling: a green technology for the preparation and functionalization of 
The Effect of Milling Time And Percentage of Dispersing Agent on The Characteristic of Solvent-Based Black Paint from Carbon Black Pigment (Ratnawati)

nanocellulose derivatis". Nanoscale Advance, pp 1-11, 2019.

[15] Testing Methods for Paint Particle Fineness. Japanese Industrial Standards Committee JIS K 5400-4.7.

[16] Test Method for Consistency of Paints Measuring Krebs Unit (KU) Viscosity Using a Stormer-Type Viscometer. ASTM D-562.

[17] Testing Methods for Paint Components (Solid Content). Japanese Industrial Standards Committee JIS K 5407-4.3.1.

[18] Testing Methods for Paint Density. Japanese Industrial Standards Committee JIS K 5400-4.6.2.

[19] Test Methods for Relative Tinting Strength of Paste Type Printing Ink Dispersion (" $L * a * b *)$. ASTM D 2066-03.

[20] O. S. Ogbonna, S. A. Akinlabi, N. Madushele. "Data showing the effects of disc milling time on the composition and morphological transformation of $(\alpha+\beta)$ titanium alloy(Ti-6Al-2Sn-2Mo-2Cr-2Zr0.25Si) grade". Data in Brief, vol 25, pp. 1-6, 2019.

[21] Y. Zheng, Z. Fu, D. Li, M. Wu. "Effects of Ball Milling Processes on the Microstructure and Rheological Properties of Microcrystalline Cellulose as a Sustainable Polymer Additive". Materials, vol 11 (1057), pp. 1-13, 2018.

[22] M. Toozandehjani, K. A. Matori, F. Ostovan, S. A. Aziz, M. S. Mamat. "Effect of Milling Time on the Microstructure, Physical and Mechanical
Properties of Al- $\mathrm{Al}_{2} \mathrm{O}_{3}$ Nanocomposite Synthesized by Ball Milling and Powder Metallurgy". Materials, vol 10(1232, pp. 1-17, 2017.

[23] Z. Song, W. Zhang, Y. Shi, J. Song, J. Qu, J. Qin, T. Zhang, Y. Li, H. Zhang, R. Zhang. "Optical Properties Across the Solar Spectrum and Indoor Thermal Performance of Cool White Coatings for Building Energy Efficiency". Energy and Buildings, vol. 63, pp.49-58, 2013.

[24] A. M. Gueli, G. Bonfiglio, S. Pasquale, S. O. Troja. "Effect of Particle Size on Pigments Colour". Color Research Application, vol. 00, pp. 1-9, 2016.

[25] J. Song, J. Qin, J. Qu, Z. Song, W. Zhang, X. Xue, Y. Shi, T. Zhang, W. Ji, R. Zhang, H. Zhang, Z. Zhang, X. Wu. "The Effects of Particle Size Distribution on The Optical Properties of Titanium Dioxide Rutile Pigments and Their Applications in Cool Non White Coatings". Solar Energy Materials \& Solar Cells, vol. 130, pp. 42-50, 2014.

[26] K. McLaren, "The Development of the CIE 1976 (L*a*b*) Uniform Color-Space and ColorDifference Formula". Coloration Technology, vol 92, pp 338-341, 2008.

[27] J. W. P. Boke. "Calcium Carbonate Particle Size Effects on Titanium Dioxide Light Scattering in Coatings". M.A. Thesis, Faculty of California Polytechnic State University: Master of Science in Polymers and Coatings, 2013. 